\title{
MACEDONIAN FOLKLORE
}

\author{
ГОДИНА / YЕAR LI \\ БРОJ / VOLUME 77-78 \\ СКОПJЕ / SKOРJE 2020
}





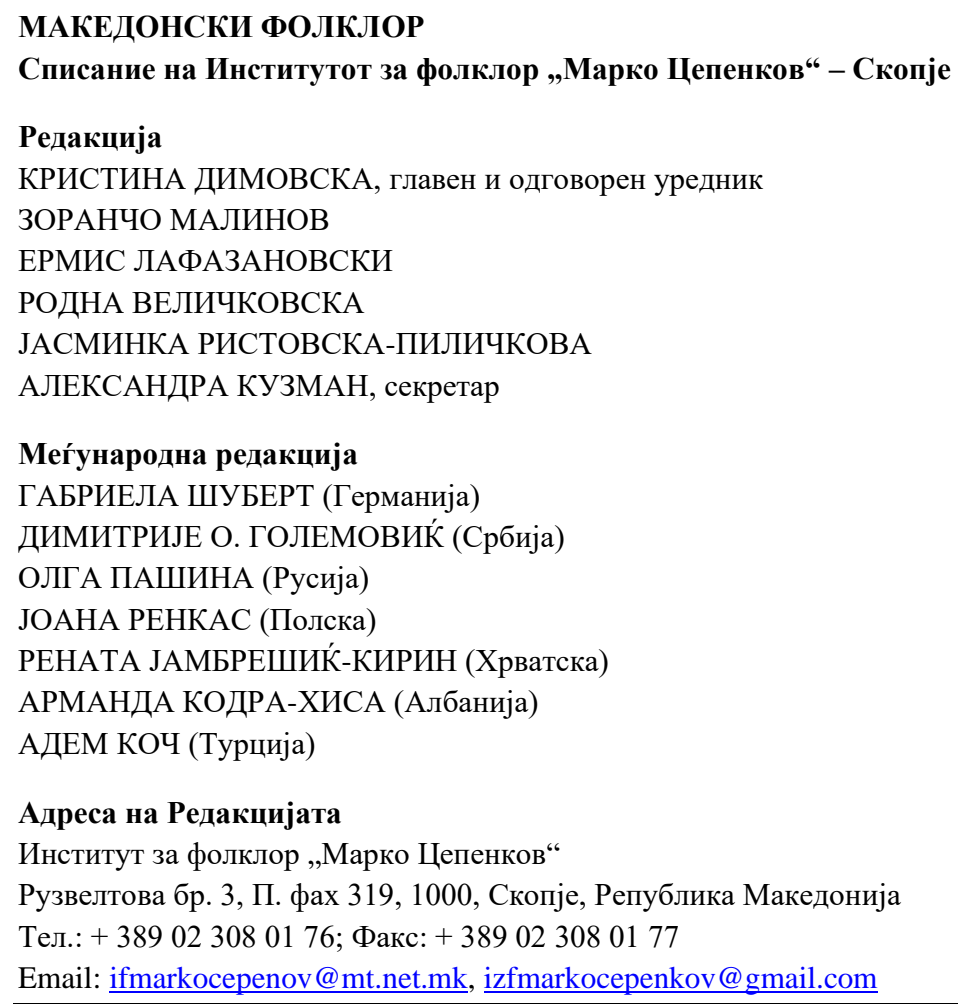



МАТЕРИЈАЛИ ОД ХХ СИМПОЗИУМ ЗА БАЛКАНСКИ ФОЛКЛОР: „ФОЛКЛОРИСТИКА: ПРЕДИЗВИЦИ И ПЕРСПЕКТИВИ“ $22-23$ ноември 2019. година, Скопје 